\title{
Wybrane metody badań środków smarowych
}

\begin{abstract}
W artykule omówione zostały właściwości fizykochemiczne środków smarowych, wybrane w oparciu o wieloletnie doświadczenie Instytutu Technicznego Wojsk Lotniczych. Problemy w eksploatacji smarowanych urządzeń wskazują na szczególne znaczenie właściwości reologicznych w zakresie niskiej i wysokiej temperatury, stabilności oksydacyjnej i mieszalności. Właściwości te, pomimo że istotne dla eksploatacji urządzeń, są stosunkowo mało znane i rzadko stosowane w praktyce laboratoryjnej wielu instytutów. Właściwości olejów smarowych i smarów plastycznych określone za pomocą omówionych w artykule testów laboratoryjnych są przydatne dla odpowiedniego ich doboru do warunków pracy smarowanych urządzeń. W artykule zastosowano terminologię zaczerpniętą z dokumentów normalizacyjnych opisujących wybrane testy laboratoryjne.
\end{abstract}

Słowa kluczowe: środki smarowe, ciecze eksploatacyjne, lepkość strukturalna, niskotemperaturowy moment obrotowy, mieszalność środków smarowych, indeks żelowania, odporność na utlenianie.

\section{Selected test methods for lubricants}

In this article selected physicochemical properties of lubricants have been discussed. The selection of properties was based on the Institute's many years of experience. Problems in the operation of lubricated equipment, indicate the particular importance of rheological properties in low and high temperature, oxidative stability and lubricants compatibility. These properties, although important for the operation of equipment, are relatively unknown and rarely used in the laboratory practice of many Institutes. The properties of lubricating oils and greases determined by the laboratory test methods described in this article, are useful for their proper selection for operating conditions of lubricated equipment. In this article, the terminology of standard test methods is used.

Key words: lubricants, operating fluids, apparent viscosity, low-temperature torque, lubricants compatibility, gelation index, oxidation stability.

\section{Wstęp}

Środki smarowe znajdują zastosowanie w wielu dziedzinach przemysłu, mają one niebagatelne znaczenie dla czasu pracy i niezawodności podzespołów różnych urządzeń mechanicznych, w tym silników. Można je klasyfikować według wielu kryteriów, np. ze względu na zastosowaną bazę (smary i oleje mineralne, półsyntetyczne, syntetyczne), a także z uwagi na przeznaczenie i pracę w określonych warunkach itp. [1].

Dynamiczny rozwój przemysłu i motoryzacji, który miał miejsce pod koniec $\mathrm{XX}$ wieku, wymusił ostrzejsze wymagania wobec stosowanych materiałów eksploatacyjnych w urządzeniach, w tym silnikach. Zaostrzenie warunków pracy, spowodowane między innymi minimalizacją wymiarów układów czy też maksymalizacją (tzw. intensyfikacją) urządzeń, sprawiły, że środki smarowe powinny sprostać technologicz- nie tym zmianom, aby zapewnić bezpieczną pracę urządzenia, w którym znajdą zastosowanie. Aby to zapewnić, muszą one spełniać określone kryteria, których zakres i wartość zależą głównie od przeznaczenia oraz warunków pracy urządzeń, do których są zaplanowane [2,3]. Kryteria te można następująco pogrupować:

- właściwości reologiczne (charakterystyka lepkościowo-temperaturowa),

- właściwości smarne,

- stabilność termiczna i termooksydacyjna,

- stabilność chemiczna,

- kompatybilność z materiałami konstrukcyjnymi,

- właściwości związane z oddziaływaniem na środowisko naturalne. 
Podział ten nie bierze pod uwagę wszystkich aspektów i może być rozszerzony, uwzględniając inne obszary eksploatacyjne. Poniżej scharakteryzowano wybrane właściwości, które wprawdzie można zaliczyć do tzw. właściwości norma- tywnych, ale ze względu na swoją specyfikację (zarówno w zakresie przeznaczenia, jak i technik realizacji badania) można zakwalifikować do grupy bardziej zaawansowanych badań, na pograniczu badań fizykochemicznych i stanowiskowych.

\section{Właściwości reologiczne środków smarowych}

\section{Lepkość strukturalna}

Istotnym parametrem w procesach eksploatacji smarów plastycznych, szczególnie lotniczych, jest lepkość strukturalna. Smary wykazują właściwości płynów nienewtonowskich, ich lepkość dynamiczna w danej temperaturze nie jest stała i zależy od szybkości ścinania, jak również czasu wywierania naprężeń. Smar nie zacznie płynąć, dopóki nadane naprężenie ścinające nie przekroczy granicy plastyczności smaru. Do tego momentu szybkość ścinania będzie zerowa. Dopiero dalsze zwiększanie naprężeń ścinających, powyżej granicy plastyczności, powoduje wzrost szybkości ścinania. Lepkość strukturalna smaru, zwana również lepkością efektywną lub lepkością pozorną, jest to lepkość dynamiczna, jaką smar wykazuje $\mathrm{w}$ warunkach badania przy określonej temperaturze i prędkości ścinania. Znajomość zależności zmian lepkości strukturalnej od prędkości ścinania jest użyteczna w prognozowaniu zachowania się smaru w układach smarowania pracujących w ustalonych warunkach przepływu i w stałej temperaturze. Pomaga także przewidzieć wyciek smaru, natężenie przepływu i spadek ciśnienia w układzie, zachowanie się smaru w niskiej temperaturze i jego pompowalności, co jest przydatne przy projektowaniu instalacji centralnego smarowania przy doborze pomp, przekrojów i długości rur, konstrukcji itp.

Lepkość strukturalna smaru jest oznaczana według normy ASTM D 1092. Zgodnie $\mathrm{z}$ tą metodą próbka smaru jest przetłaczana pod ustalonym natężeniem przypływu przez ka-

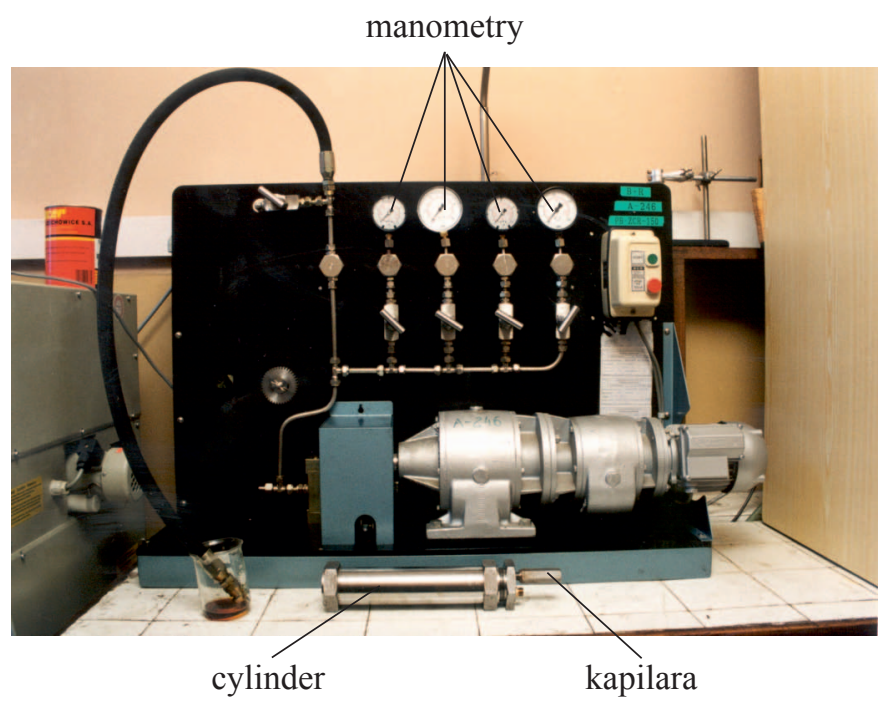

Rys. 1. Widok stanowiska do oznaczania lepkości strukturalnej (ITWL) pilarę przy użyciu tłoka pracującego w układzie hydraulicznym (rysunek 1). Lepkość strukturalną oblicza się z równania Poiseuille'a na podstawie średnicy użytej kapilary, znanego natężenia przepływu i ciśnienia wymaganego do wymuszenia przepływu smaru pod zadanym natężeniem przepływu. Przy użyciu kompletu ośmiu kapilar i zastosowaniu dwóch prędkości obrotowych pompy możliwe jest oznaczanie lepkości strukturalnej w danej temperaturze dla szesnastu prędkości ścinania. Wyniki są przedstawiane graficznie w układzie podwójnie logarytmicznym w postaci wykresu zależności lepkości strukturalnej od prędkości ścinania.

\section{Niskotemperaturowy moment obrotowy}

Wraz ze spadkiem temperatury wzrasta lepkość smaru i dlatego też wymagane jest przyłożenie większej siły w celu pokonania oporów ruchu. Jeżeli działająca w układzie smarowania siła będzie zbyt mała, to elementy trące przestaną się obracać, w wyniku czego może dojść do uszkodzenia urządzenia. Do oceny zachowywania się smarów plastycznych w niskiej temperaturze wykorzystuje się pomiar tzw. niskotemperaturowego momentu obrotowego. Parametr ten określa wpływ działania niskiej temperatury na smar poprzez pomiar sił hamujących, działających na przemieszczające się elementy układu tarcia smarowanego analizowanym produktem. Badanie to jest stosowane do określania przydatności smarów w układach pracujących w ustalonych warunkach zewnętrznych.

Niskotemperaturowy moment obrotowy dla smarów do łożyskowych układów w zastosowaniach lotniczych oznacza się według normy ASTM D 1478. Badanie polega na umieszczeniu otwartego łożyska kulkowego, napełnionego badanym smarem, w komorze chłodniczej. Łożysko przetrzymuje się nieruchomo przez dwie godziny, podczas gdy temperatura jest obniżana do temperatury badania (określonej w specyfikacji smaru). Pod koniec tego czasu wewnętrzny pierścień łożyska jest obracany z prędkością $1 \mathrm{obr} / \mathrm{min}$ (rysunek 2). Podczas tej czynności mierzona jest siła oporu, jaką stawia zewnętrzny pierścień. Moment obrotowy jest określany przez pomnożenie zmierzonej siły oporu przez promień wieńca kulek. Określa się moment rozruchowy oraz moment po 60 minutach pracy.

Badanie według normy ASTM D 4693 znajduje zastosowanie do pomiaru niskotemperaturowego momentu obrotowego dla smarów do łożysk kół samochodowych (rysunek 3). Świeżo wymieszana i ugnieciona próbka badanego 
smaru jest wprowadzona do specjalnie wykonanych zespołów łożysk samochodowych typu wrzeciono-piasta. Zespół podgrzewa się, a następnie umieszcza w temperaturze $-40^{\circ} \mathrm{C}$ i schładza przez 5 godzin. Wrzeciono obraca się z prędkością $1 \mathrm{obr} / \mathrm{min}$, moment obrotowy wymagany do powstrzymania obrotów piasty jest mierzony przez 60 sekund, a następnie zostaje obliczony z iloczynu zmierzonej siły oporu i odległości pomiędzy wałem a osią przetwornika tensometrycznego.

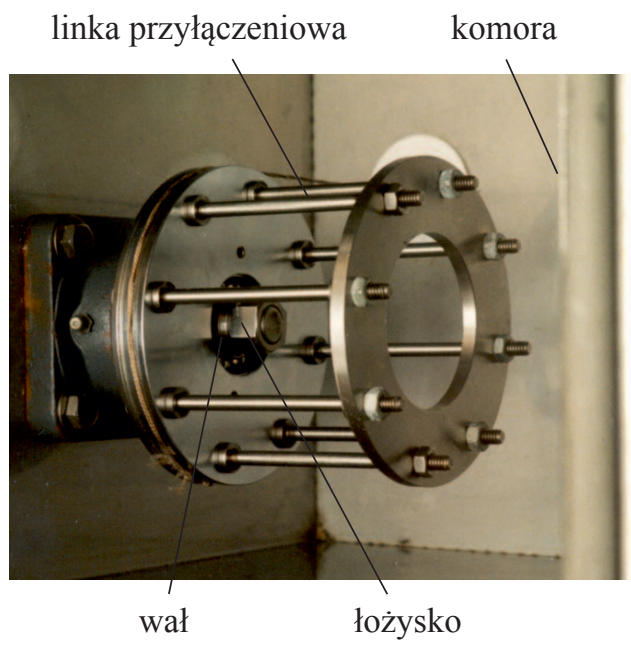

Rys. 2. Widok zespołu testowego stanowiska do badania momentu obrotowego według ASTM D 1478 (ITWL)

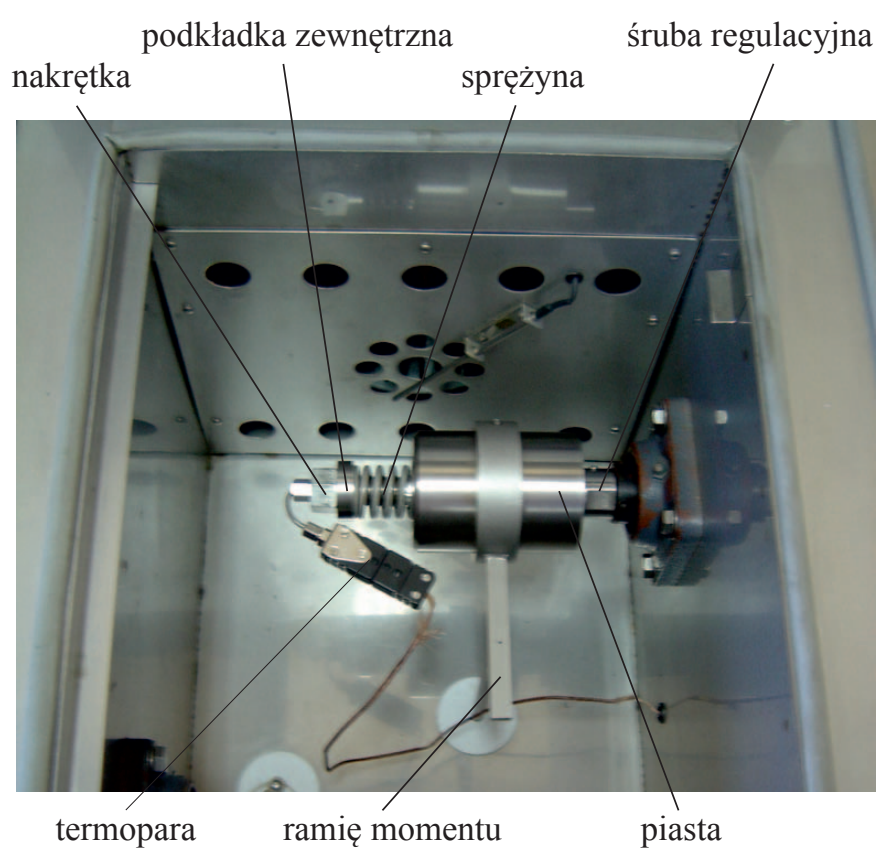

Rys. 3. Widok zespołu testowego stanowiska do badania momentu obrotowego według ASTM D 4693 (ITWL)

\section{Mieszalność}

Podczas obsługi instalacji przemysłowych lub innych urządzeń zachodzi niejednokrotnie potrzeba wymiany zużytego środka smarnego. Czasami jest to wymiana na inny środek (np. innego producenta). Może wtedy dojść do zmie- szania się części pozostałego w układzie środka smarowego z nowo wprowadzonym. Jeżeli środki te nie są ze sobą kompatybilne, to może wystąić wydzielanie się dodatków będących komponentami środka smarowego, rozwarstwienie, powstawanie nierozpuszczalnych związków itp. W efekcie dochodzi do pogorszenia właściwości użytkowych środka smarowego, np. w przypadku olejów smarowych może wywołać to wzrost skłonności do pienienia lub utratę zdolności do wydzielania wody. Wytrącone osady, gromadząc się na ściankach przewodów i filtrów, powodują nawet niedrożność układu smarowania, co w konsekwencji prowadzi do awarii urządzeń. Biorąc pod uwagę istotę znaczenia niezawodności maszyny, w wielu przypadkach uzasadniona jest potrzeba badania mieszalności środków smarowych przy ich zmianie, dzięki czemu można przewidzieć potencjalne problemy operacyjne.

Ogólna zasada badania mieszalności polega na zmieszaniu badanego środka smarowego ze środkiem wzorcowym lub środkiem wcześniej stosowanym, w określonych stosunkach, i poddaniu mieszanek cyklom termostatowania w zmiennych warunkach temperatury. Po zakończonym termostatowaniu dokonuje się oceny wizualnej mieszanek lub przeprowadza stosowne badania fizykochemiczne.

\section{Mieszalność smarów plastycznych}

Według normy PN-V-04046 badanie mieszalności smarów plastycznych polega na termostatowaniu próbek w znormalizowanych warunkach. Następnie mieszankę smarów poddaje się wybranym badaniom z zakresu: działania korodującego smaru na metale, skłonności do wydzielania się smarów plastycznych z łożysk kół samochodowych, penetracji smaru po ugniataniu, temperatury kroplenia smarów plastycznych i stabilności mechanicznej dla smarów plastycznych. Jeżeli zbadane właściwości spełniają wymagania stawiane smarom w normie przedmiotowej, to wynik badania mieszalności jest pozytywny.

\section{Mieszalność olejów smarowych}

Według metodyki badawczej MB-MPS-009 badanie wykonuje się dla syntetycznych olejów silnikowych i polega ono na termostatowaniu mieszanek olejów w okresie 5 cykli. Każdy cykl składa się z: 8 godzin przechowywania w temperaturze $-40^{\circ} \mathrm{C}, 16$ godzin przechowywania w temperaturze $20^{\circ} \mathrm{C}$ i 8 godzin przechowywania w temperaturze $130^{\circ} \mathrm{C}$. Termostatowanie mieszanek przeprowadza się w komorze utrzymującej powyższe warunki. Temperatura jest monitorowana w sposób ciągły. Po zakończeniu badania dokonuje się wizualnej oceny mieszanek. Jakiekolwiek zmętnienie czy niejednorodność mieszanek lub obecne w nich osady są podstawą do stwierdzenia niekompatybilności środków smarowych. 


\section{Indeks żelowania}

W warunkach niskotemperaturowych olej silnikowy może stać się niezdolnym do smarowania silnika. Główną przyczyną tego może być utrata płynności, która spowoduje, że niewystarczająca ilość oleju wypływającego z miski dotrze do kolektora olejowego. W zależności od składu oleju w wyniku schładzania może dojść do jego żelowania. Proces ten jest związany ze zmianą właściwości składników oleju w niskiej temperaturze i zmianą jego struktury. W efekcie tego może wytworzyć się stan napowietrzenia lub ograniczonego przypływu, co spowoduje, że olej nie będzie mógł wpłynąc do kanału wlotowego, a następnie do pompy olejowej w ilościach wystarczających do tego, aby pompa w sposób ciągły dostarczała go do obszarów krytycznych silnika (krótko po jego uruchomieniu). Jeżeli to nastąpi, to może dojść do uszkodzenia silnika.

Do oceny właściwości reologicznych oleju silnikowego w niskiej temperaturze i przy niskiej szybkości ścinania służy Skaningowa Metoda Brookfielda (rysunek 4). Pozwala ona wyznaczyć parametry potrzebne do oceny pompowalności oleju i zdolność do żelowania za pomocą tzw. indeksu żelowania, który określa intensywność ścinania i pozwala ocenić olej pod względem jego zdolności do utraty płynności.

Zasada metody opisanej w normie ASTM D 5133 polega na ciągłym pomiarze lepkości dynamicznej oleju w funkcji temperatury podczas obrotu rotatora z prędkością $0,3 \mathrm{obr} / \mathrm{min}$, przy obniżaniu temperatury ze stałą prędkością $1^{\circ} \mathrm{C} / \mathrm{h}$ od temperatury początkowej $-5^{\circ} \mathrm{C}$ do temperatury końcowej $-40^{\circ} \mathrm{C}$ lub do temperatury, w której lepkość przekroczy wartość $40000 \mathrm{mPa} \cdot \mathrm{s}$. Dane w trakcie pomiaru są rejestrowane i zapisywane. Na ich podstawie wyznacza się indeks żelowania.

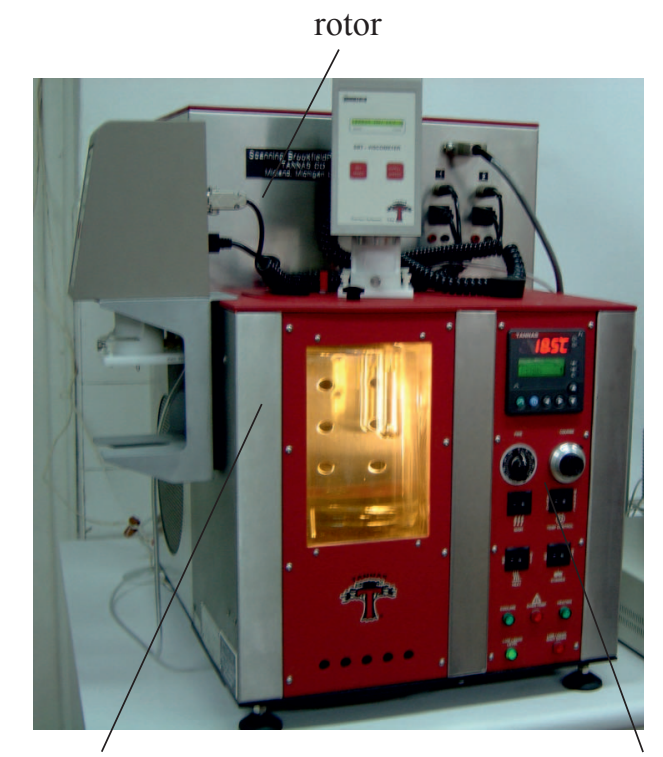

probówka na próbkę panel sterowniczy

Rys. 4. Widok stanowiska badawczego do oznaczania indeksu i temperatury żelowania (ITWL)

\section{Termiczna stabilność oksydacyjna}

Podczas pracy oleju w skojarzeniach ciernych zachodzi proces jego utleniania, szczególnie ułatwiony w czasie smarowania, gdy olej znajduje się w postaci cienkiej warstwy, w podwyższonej temperaturze, przy jednoczesnym katalitycznym wspomaganiu utleniania przez metaliczne podłoże. W wyniku reakcji tlenu z węglowodorami obecnymi w oleju dochodzi do powstawania między innymi produktów kwasowych, które mogą powodować procesy korozyjne układu. Działanie tlenu dodatkowo wywołuje odwodornienie i kondensację węglowodorów aromatycznych, co prowadzi do powstawania substancji asfaltowo-żywicznych. W dalszych stadiach przyczynia się to do powstawania bogatych w węgiel cząstek stałych, które - osadzając się na powierzchniach współpracujących elementów układu tarcia - powodują jego nadmierne zużywanie, prowadzące do zatarcia. Proces utleniania pogorsza właściwości oleju, przyczyniając się do poważnych problemów użytkowych sprzętu.

Jedną z metod oceny odporności olejów na utlenianie w wysokiej temperaturze jest tzw. test L-60-1 według normy ASTM D 5704, wykonywany dla olejów przeznaczonych do smarowania samochodowych manualnych skrzyń biegów i wałków przekładni głównych (rysunek 5).

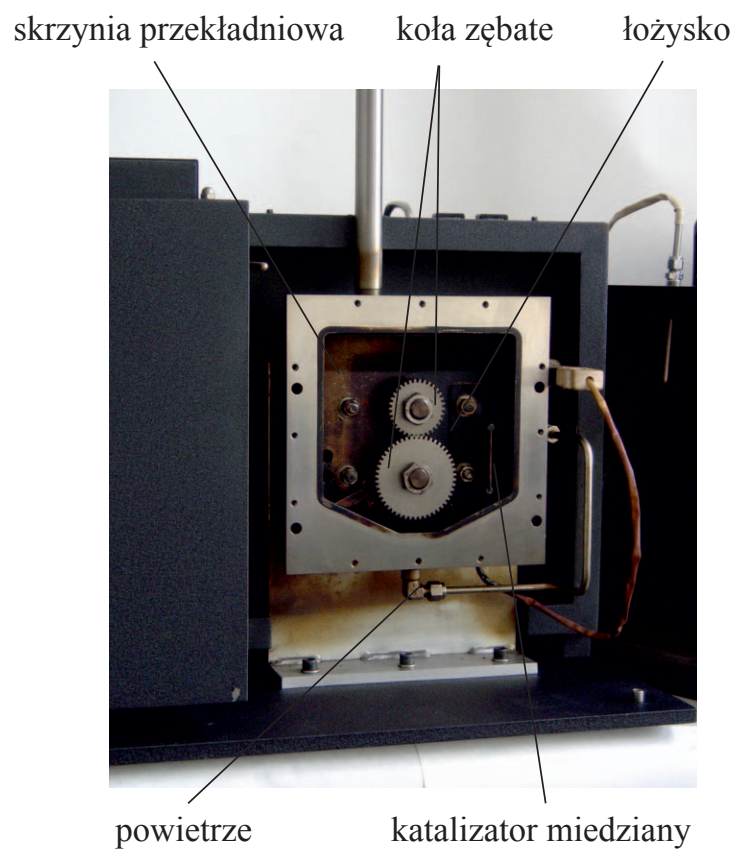

Rys. 5. Widok stanowiska do oceny stabilności oksydacyjnej olejów według ASTM D 5704 (ITWL)

Próbka badanego produktu jest umieszczana w podgrzewanej skrzynce przekładniowej, w której pracują dwa koła zębate i łożysko testowe, przy określonym obciążeniu i prędkości obrotowej w obecności katalizatora miedzianego. Przez olej przedmuchiwane jest $\mathrm{z}$ określoną prędkością powietrze, a temperatura oleju jest utrzymywana na zadanym poziomie 
w czasie 50-godzinnego testu. Odporność oleju na utlenianie ocenia się poprzez ubytek masy oleju i katalizatora, zmianę lepkości kinematycznej i całkowitej liczby kwasowej, zawartość w oleju nierozpuszczalnych zanieczyszczeń oraz wygląd osadów na powierzchni kół zębatych i katalizatora.

Inną metodę oceny opisano w normie PN-C-04365 stosowanej do badania hydraulicznych i turbinowych olejów lotniczych. Szklaną probówkę zawierającą badaną próbkę i zestaw płytek metalowych umieszcza się w łaźni o stałej temperaturze i ogrzewa przez określoną liczbę godzin, w warunkach przepływu powietrza przez olej - zapewniającego mieszanie i źródło tlenu. Odporności oleju na utlenianie ocenia się poprzez określenie zmiany lepkości kinematycznej, całkowitej liczby kwasowej i zawartości w nim osadów. Ocenia się także działanie korodujące oleju na podstawie zmiany masy płytek metalowych oraz obserwacji ich wyglądu zewnętrznego.

\section{Podsumowanie}

W celu zapewnianie niezawodności i wysokiej jakości środków smarowych konieczne są badania fizykochemiczne gotowego wyrobu, mające na celu potwierdzenie spełnienia stawianych mu wymagań. Oprócz typowych badań, wykonywanych rutynowo podczas kontroli partii wyrobu, takich jak np. lepkość kinematyczna olejów smarowych czy też penetracja smarów plastycznych, stosowane są również badania wyspecjalizowane, prowadzone w sposób i w warunkach bardziej zbliżonych do rzeczywistych, przez co lepiej oddających właściwości i zachowanie środków smarowych podczas ich eksploatacji. Badania tego typu umożliwiają dobór właściwego środka smarowego do warunków pracy i prognozowanie zmian jego właściwości w trakcie użytkowania, tym samym stanowią znakomite uzupełnienie dla rutynowych badań fizykochemicznych. W artykule przedstawiono przykładowe badania z zakresu tej tematyki wraz z uwzględnieniem ich zastosowania, które są prowadzone w Laboratorium MPS ITWL.

Prosimy cytować jako: Nafta-Gaz 2017, nr 11, s. 894-898, DOI: 10.18668/NG.2017.11.10

Artykuł nadesłano do Redakcji 19.06.2017 r. Zatwierdzono do druku 31.07.2017 r.

\section{Literatura}

[1] Strona internetowa: http://glowny-mechanik.pl/2015/09/09/ klasyfikacja-srodkow-smarnych/ (dostęp: 3.04.2017).

[2] Zwierzycki W.: Oleje smarowe: dobór i użytkowanie. Gorlice: Rafineria Nafty „Glimar”, Radom: Instytut Technologii Eksploatacji, 1998.

[3] Zwierzycki W.: Paliwa, oleje, motoryzacyjne plyny eksploatacyjne. Gorlice: Rafineria Nafty „Glimar”, Radom: Instytut Technologii Eksploatacji, 1998.

\section{Akty prawne i normatywne}

[4] ASTM D 1092 Standard Test Method for Measuring Apparent Viscosity of Lubricating Grease.

[5] ASTM D 1478 Standard Test Method for Low-Temperature Torque of Ball Bearing Grease.

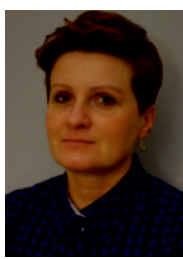

Inż. Marzena ŁOSIEWICZ

Inżynier w Zakładzie Materiałów Pędnych i Smarów

Pracownia Badań Laboratoryjnych

Instytut Techniczny Wojsk Lotniczych

ul. Ostroroga 35A

01-163 Warszawa

E-mail: marzena.losiewicz@itwl.pl
[6] ASTM D 4693 Standard Test Method for Low-Temperature Torque of Grease-Lubricated Wheel Bearings.

[7] ASTM D 5133 Standard Test Method for Low Temperature, Low Shear Rate, Viscosity/Temperature Dependance of Lubricating Oils Using a Temperature-Scanning Technique.

[8] ASTM D 5704 Standard Test Method for Evaluation of the Thermal and Oxidative Stability of Lubricating Oils Used for Manual Transmissions and Final Drive Axles.

[9] MB-MPS-009 Mieszalność olejów silnikowych.

[10] PN-C-04365 Przetwory naftowe - Badanie dziatania korodujacego i odporności na utlenianie olejów.

[11] PN-V-04046 Przetwory naftowe-Badanie mieszalności smarów plastycznych.

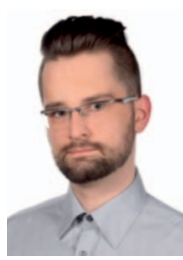

Inż. Dawid KAPICA

Inżynier w Zakładzie Materiałów Pędnych i Smarów Pracownia Badań Laboratoryjnych Instytut Techniczny Wojsk Lotniczych ul. Ostroroga 35A 01-163 Warszawa E-mail:dawid.kapica@itwl.pl 